\title{
Perilaku Berkendara Agresif Para Pengguna Kendaraan Bermotor di Kota Malang
}

\author{
Ika Herani, Anya Khaleda Jauhari \\ herani@ub.ac.id \\ Jurusan Psikologi, Universitas Brawijaya, Malang, Indonesia
}

\begin{abstract}
This study aims to identify the types of aggressive driving behavior and their causative factors. Survey method was employed in this study. The population of this study was motorized vehicle users (drivers and riders) in the city of Malang, from which we drew 400 drivers and riders as our sample by using purposive sampling technique. Data obtained from this study was then analyzed by applying descriptive and frequency analysis technique. The results showed that the most frequent type of aggressive driving behavior was tailgating in order to prevent others from occupying the space. Furthermore, contributing factors of aggressive driving behavior were traffic density, rushing behavior, some burdersome traffic signs, and other motorized vehicle users who try to occupy their driving territory.

Penelitian ini bertujuan untuk mengetahui bentuk-bentuk perilaku berkendara agresif beserta faktor yang menjadi pemicunya. Metode yang digunakan dalam penelitian ini adalah metode survei. Populasi penelitian ini adalah para pengguna kendaraan bermotor (pengendara mobil dan sepeda motor) di Kota Malang, dengan jumlah sampel 400 orang. Metode pengambilan data pada penelitian ini adalah teknik purposive sampling. Data yang diperoleh kemudian dianalisis dengan menggunakan teknik analisis deskriptif dan analisis frekuensi. Hasil dari penelitian ini menunjukkan bahwa perilaku berkendara agresif yang dominan terjadi adalah memperkecil jarak kedekatan dengan kendaraan di depannya untuk menghalangi pengendara lain yang akan mengambil jalan. Sementara itu, faktor yang menjadi pemicu terjadinya perilaku berkendara agresif adalah kepadatan lalu lintas, terburu-buru, rambu lalu lintas yang dirasa memberatkan pengendara, dan adanya pengendara lain yang melanggar daerah teritori pengendara tersebut.
\end{abstract}

Kata kunci: perilaku berkendara agresif

Received: July 28, 2017 Accepted: December 13, 2017

How to cite: Herani, I., \& Jauhari, A. K. (2017). Perilaku berkendara agresif para pengguna kendaraan bermotor di Kota Malang. MEDIAPSI, 3(2), 29-38. doi:http://dx.doi.org/10.21776/ub.mps.2017.003.02.4

\section{Pendahuluan}

Kota Malang merupakan salah satu kota terbesar di Jawa Timur setelah Kota Surabaya. Malang juga dikenal sebagai kota pelajar seperti Daerah Istimewa Yogyakarta karena memiliki sejumlah perguruan tinggi ternama. Terdapat sebanyak 12 perguruan tinggi yang berdiri di Kota Malang (Biro Pusat Statistik, 2013). Hal tersebut merupakan salah satu faktor yang mendorong Kota Malang banyak didatangi para pelajar dari berbagai daerah di Indonesia bahkan dari negara-negara lain di luar Indonesia untuk mencari ilmu, sehingga tidak heran apabila Malang mengalami perkembangan jumlah penduduk yang pesat.

Semakin banyak warga pendatang, maka kepadatan penduduk Kota Malang juga semakin meningkat dan hal tersebut sekaligus menjadi pemicu kemacetan lalu lintas. Bertambahnya penduduk pendatang yang mayoritas merupakan mahasiswa dari luar Kota Malang yang sebagian besarnya membawa kendaraan pribadi seperti kendaraan roda dua (motor) dan kendaraan roda empat (mobil) merupakan salah satu pemicu kemacetan lalu lintas. Semakin banyak 
penduduk maka semakin tinggi pula volume kendaraaan bermotor yang berlalu lalang.

Meningkatnya jumlah penduduk yang disertai peningkatan pada jumlah kendaraan bermotor di Kota Malang menyebabkan kepadatan lalu lintas yang cukup tinggi dan mengakibatkan banyak titik kemacetan yang muncul di jalan-jalan utama perkotaan. Biasanya perilaku yang ditunjukkan di saat kondisi padat dan sesak tersebut adalah mengemudi dengan jarak yang terlalu dekat dengan kendaraan lain atau menyalip dan menyerobot kendaraan lain yang ada di depannya. Perilaku lain yang mungkin akan muncul antara lain mengumpat, mengklakson, berteriak, dan terkadang hingga timbul perselisihan antara pengemudi pengguna jalan. Perilaku yang disebutkan di atas merupakan uraian perilaku-perilaku yang sering kali disebut sebagai perilaku berkendara agresif. Perilaku berkendara agresif itu sendiri menurut James dan Nahl (2000) adalah mengemudi di bawah pengaruh gangguan emosi, yang menghasilkan tingkah laku yang memaksakan suatu resiko pada pengemudi lain. Dikatakan agresif karena dapat diasumsikan bahwa orang lain mampu menangani tingkat resiko yang sama dan diasumsikan bahwa seseorang berhak meningkatkan resiko orang lain untuk terkena bahaya.

Perilaku pengendara sepeda motor yang sering menyalahi aturan lalu lintas serta kecerobohan dalam berkendara tersebut termasuk dalam perilaku berkendara agresif. Tasca (2000) menyatakan bahwa perilaku mengemudi dikatakan agresif jika dilakukan secara sengaja, cenderung meningkatkan resiko kecelakaan, dan dimotivasi oleh ketidaksabaran, kekesalan, permusuhan, dan upaya menghemat waktu. Dengan demikian, perilaku berkendara agresif dalam penelitian ini adalah pengendara mobil dan motor di Kota Malang yang dipengaruhi oleh emosi yang tidak stabil, sehingga menghasilkan perilaku yang berakibat meningkatkan resiko terhadap pengguna jalan lainnya.

Ada tiga bentuk perilaku berkendara agresif menurut James dan Nahl (2000), yaitu impatience and inattention (tidak sabar dan tidak perhatian) contohnya seperti melanggar lampu merah dan melanggar batas kecepatan. Selanjutnya adalah power struggle (saling berebut), contohnya yaitu memotong jalur dengan sengaja dan mengancam atau menghina dengan kata-kata, isyarat, juga mengklason terus-menerus. Terakhir, recklessness and road rage (ceroboh dan marah-marah), seperti berkendara sambil mabuk dan berkendara dengan kecepatan sangat tinggi.

Berdasarkan tiga bentuk perilaku agresif yang telah dijelaskan sebelumnya, perilaku tersebut menurut James dan Nahl (2000) disebabkan oleh 15 faktor, yaitu immobility, restriction, regulation, lack of personal control, being put in danger, territoriality, diversity, multi-tasking, denial, negativity, self-serving bias, venting, unpredictability, isolation, dan emotional challenges. Tujuan dilakukannya penelitian ini adalah untuk Mendapatkan gambaran mengenai bentukbentuk aggressive driving behavior dan mengetahui faktor-faktor apa saja yang memicu munculnya bentuk-bentuk perilaku berkendara agresif tersebut pada para pengguna kendaraan bermotor di Kota Malang.

\section{Metode}

\section{Desain penelitian}

Peneliti menggunakan jenis metode penelitian survei deskriptif. Metode survei 
deskriptif merupakan penelitian yang bertujuan untuk menggambarkan suatu gejala (fenomena) atau sifat tertentu, akan tetapi tidak untuk mencari atau menerangkan keterkaitan antara variabel.

\section{Responden}

Responden dalam penelitian ini adalah para pengguna kendaraan bermotor (motor dan mobil) di Kota Malang. Pengambilan sampel pada penelitian ini menggunakan pendekatan non-probability sampling dengan teknik purposive sampling. Teknik purposive sampling merupakan cara pengambilan sampel berdasarkan kriteria yang sudah ditentukan. Dari sisi rentang perkembangannya, sampel dalam penelitian ini masuk ke dalam kategori dewasa madya. Adapun kriteria sampel yang ditetapkan pada penelitian ini adalah menggunakan kendaraan bermotor dan pengguna jalan di Kota Malang.

\section{Data penelitian}

Penelitian ini menggunakan kuesioner yang disusun peneliti berdasarkan teori perilaku berkendara agresif dari James dan Nahl (2000). Terdapat tiga bagian dalam kuesioner tersebut. Bagian pertama berisi pertanyaan mengenai demografis data subjek yang persentasenya dihitung melalui program Excel dan SPSS. Bagian kedua merupakan skala mengenai faktor penyebab perilaku berkendara agresif. Peneliti menggunakan kuesioner dalam bentuk pernyataan, yang mana pernyataan mengenai faktor penyebab perilaku berkendara agresif peneliti susun berdasarkan Skala Guttman. Sementara itu, bagian ketiga berisi skala mengenai bentukbentuk perilaku berkendara agresif.

Responden diperbolehkan untuk memberikan lebih dari satu jawaban sesuai dengan apa yang mereka lakukan pada saat berkendara. Apabila dari pilihan jawaban yang telah disediakan tidak ada yang sesuai, maka responden dapat memberikan jawaban mereka sendiri dengan mengisi bagian "lain-lain". Peneliti menggunakan pertanyaan terbuka sebagian. Pertanyaan terbuka sebagian merupakan jenis pertanyaan penelitian survei yang respondennya diberi serangkaian pilihan jawaban, tetapi tambahan kategori "lain-lain" juga diberikan sehingga responden dapat menyebutkan jawaban yang berbeda (Neuman, 2013).

\section{Analisis data}

Analisis data dalam penelitian ini menggunakan teknik analisis deskriptif dan analisis frekuensi.

\section{Hasil}

Setelah dilakukan analisis data secara terperinci terhadap respon dari 400 subjek penelitian mengenai 15 faktor yang menjadi penyebab perilaku berkendara agresif pengendara kendaraan bermotor di Kota Malang, diperoleh hasil analisis sebagaimana dipaparkan selengkapnya pada Tabel 1.

Berdasarkan hasil analisis, diketahui bahwa faktor penyebab perilaku berkendara agresif yang paling tinggi untuk komponen immobility adalah ketika pengendara kendaraan bermotor di Kota Malang sebanyak $64.75 \%$ tidak dapat melewati celah di antara dua kendaraan sebesar. Dalam konteks ini, pengemudi kendaraan bermotor di Kota Malang akan mengklakson berkali-kali pengendara yang berjalan lambat di depan pengendara tersebut. Sementara itu, faktor penyebab perilaku berkendara agresif yang paling tinggi untuk komponen restriction adalah ketika pengendara lain melewati kendaraan lain melalui celah jalan yang dapat dilalui dengan cepat yang mendapat respon 
sebesar $65 \%$. Dalam konteks ini, pengemudi kendaraan bermotor di Kota Malang memakai bahu jalan untuk menyalip agar lebih cepat saat terjadi kemacetan.

Tabel 1

Analisis Frekuensi 15 Faktor Penyebab Perilaku Berkendara Agresif Pengendara Kendaraan Bermotor di Kota Malang

\begin{tabular}{|c|c|c|c|c|}
\hline Komponen & Ya & Persentase & Tidak & Persentase \\
\hline \multirow{4}{*}{ Immobility } & 231 & $57.75 \%$ & 169 & $42.25 \%$ \\
\hline & 252 & $63 \%$ & 148 & $37 \%$ \\
\hline & 259 & $64.75 \%$ & 141 & $35.25 \%$ \\
\hline & 209 & $52.25 \%$ & 191 & $47.75 \%$ \\
\hline \multirow{3}{*}{ Restriction } & 260 & $65 \%$ & 140 & $35 \%$ \\
\hline & 110 & $27.5 \%$ & 290 & $72.50 \%$ \\
\hline & 66 & $16.5 \%$ & 334 & $83.5 \%$ \\
\hline \multirow{2}{*}{ Regulation } & 232 & $58 \%$ & 168 & $42 \%$ \\
\hline & 210 & $52.5 \%$ & 190 & $47.50 \%$ \\
\hline Lack of & 86 & $21.5 \%$ & 314 & $78,5 \%$ \\
\hline Personal & 249 & $62.25 \%$ & 151 & $37.75 \%$ \\
\hline Control & 216 & $54 \%$ & 184 & $46 \%$ \\
\hline \multirow{3}{*}{$\begin{array}{l}\text { Being Put in } \\
\text { Danger }\end{array}$} & 246 & $61.5 \%$ & 154 & $38.5 \%$ \\
\hline & 78 & $19.5 \%$ & 322 & $80.5 \%$ \\
\hline & 218 & $54.5 \%$ & 182 & $45.5 \%$ \\
\hline Territoriality & 271 & $67.75 \%$ & 129 & $32.25 \%$ \\
\hline \multirow{2}{*}{ Diversity } & 223 & $55.75 \%$ & 177 & $44.25 \%$ \\
\hline & 74 & $18.5 \%$ & 326 & $81.50 \%$ \\
\hline \multirow{4}{*}{$\begin{array}{l}\text { Multi- } \\
\text { Tasking }\end{array}$} & 210 & $52.5 \%$ & 190 & $47.5 \%$ \\
\hline & 209 & $52.25 \%$ & 191 & $47.75 \%$ \\
\hline & 190 & $47.5 \%$ & 210 & $52.5 \%$ \\
\hline & 155 & $38.75 \%$ & 245 & $61.25 \%$ \\
\hline Denial & 206 & $51.5 \%$ & 194 & $48.5 \%$ \\
\hline \multirow{3}{*}{ Negativity } & 96 & $24 \%$ & 304 & $76 \%$ \\
\hline & 208 & $52 \%$ & 192 & $48 \%$ \\
\hline & 206 & $51.5 \%$ & 194 & $48.5 \%$ \\
\hline \multirow{2}{*}{$\begin{array}{l}\text { Self-Serving } \\
\text { Bias }\end{array}$} & 221 & $55.25 \%$ & 179 & $44.75 \%$ \\
\hline & 215 & $53.75 \%$ & 185 & $46.25 \%$ \\
\hline \multirow{2}{*}{ Venting } & 255 & $63.75 \%$ & 145 & $36.25 \%$ \\
\hline & 247 & $61.75 \%$ & 153 & $38.25 \%$ \\
\hline \multirow{2}{*}{$\begin{array}{l}\text { Unpredicta- } \\
\text { bility }\end{array}$} & 267 & $66.75 \%$ & 133 & $33.25 \%$ \\
\hline & 220 & $55 \%$ & 180 & $45 \%$ \\
\hline \multirow{2}{*}{ Isolation } & 201 & $50.25 \%$ & 199 & $49.75 \%$ \\
\hline & 115 & $28.75 \%$ & 285 & $71.25 \%$ \\
\hline Emotional & 84 & $21 \%$ & 316 & $79 \%$ \\
\hline Challenges & 243 & $60.75 \%$ & 157 & $39.25 \%$ \\
\hline
\end{tabular}

Faktor penyebab perilaku berkendara agresif yang paling tinggi untuk komponen regulation adalah ketika pengendara merasa lampu merah sangat memberatkan sehingga pengendara akan cenderung berkendara dengan cepat pada saat melihat lampu kuning akan berganti merah, yang mendapat respon sebesar 58\%. Dalam konteks ini, pengemudi kendaraan bermotor di Kota Malang akan menambah kecepatan kendaraan mereka saat lampu kuning menyala. Sementara itu, untuk komponen lack of personal control, respon paling tinggi adalah ketika pengendara terpancing emosinya saat suasana lalu lintas macet dan atau kondisi jalan tidak tertib yang mendapat respon sebesar $62.25 \%$. Dalam konteks ini, pengemudi kendaraan bermotor di Kota Malang terpancing untuk melakukan hal yang sama ketika ada pengendara lain yang memotong jalur pengendara tersebut.

Faktor penyebab perilaku berkendara agresif paling tinggi untuk komponen being put in danger adalah ketika pengendara memotong jalur di jalan raya kemudian perilakunya diikuti oleh pengendara lain yang mendapat respon sebesar 61.5\%. Dalam konteks ini ketika subjek memotong jalur pengendara lain, subjek melihat pengendara tersebut mengikuti perilaku subjek dengan membalas memotong jalur subjek. Komponen territioriality memiliki respon paling tinggi berupa perilaku pengendara yang memandang tajam pengendara lain yang berada di sisi kendaraannya, dengan respon sebesar $67.75 \%$. Dalam konteks ini, pengendara kendaraan bermotor di Kota Malang akan menatap sinis atau tajam jika pengendara lain berbuat onar atau tidak menyenangkan kepada pengendara tersebut.

Faktor penyebab perilaku berkendara agresif paling tinggi untuk komponen diversity adalah berkendara dengan kecepatan tinggi karena terburu-buru ingin sampai pada tujuan yang mendapat respon sebesar $55.75 \%$, sehingga dalam konteks ini, pengendara kendaraan bermotor di Kota Malang cenderung memacu kendaraannya dengan kecepatan tinggi karena terburu-buru ingin 
sampai tujuan tepat waktu. Tidak jauh berbeda dengan komponen diversity, respon paling tinggi untuk komponen multi-tasking adalah berupa pengendara lain menatap pengendara yang dianggap tidak mampu berkendara karena terlihat kerepotan dalam pengoperasian alat kemudi di jalan raya yang mendapat respon sebesar 52.5\%. Komponen denial dengan indikator berupa pengendara lain memaksa pengendara untuk menyingkir dari jalur cepat karena dianggap dirinya berkendara terlalu lambat mendapat respon sebesar 51.5\%, yang bermakna bahwa pengendara kendaraan bermotor di Kota Malang berkendara di jalur kanan dengan kecepatan yang berbeda-beda, sehingga pengemudi kendaraan di belakang sering memberikan tanda agar pengemudi segera berpindah jalur.

Sementara itu, faktor penyebab perilaku berkendara agresif paling tinggi untuk komponen negativity adalah saat pengendara memperlihatkan mimik muka yang tidak menyenangkan karena pernah terlibat dalam masalah dengan kendaraan yang serupa, dengan respon sebesar 65.5\%. Dalam konteks ini, pengendara tidak suka ketika melihat kendaraan lain ugal-ugalan, karena pengendara tersebut pernah terlibat kejadian yang tidak mengenakkan. Faktor penyebab perilaku berkendara agresif paling tinggi pada komponen self-serving bias adalah ketika pengendara tidak mau disalahkan terlibat dalam suatu kecelakaan karena perilakunya, yang mendapat respon sebesar 55.25\%. Dalam konteks ini, pengendara kendaraan bermotor di Kota Malang akan marah ketika pengendara di belakang kendaraannya menabraknya saat pengendara berbelok, padahal pengendara tersebut merasa sudah memberikan tanda (menyalakan lampu sign). Sementara itu, pada komponen venting, respon paling tinggi adalah ketika pengendara lain mendahului kendaraan pengendara dalam jarak yang sangat dekat pada saat lalu lintas padat, dengan respon sebesar $63.75 \%$. Dalam konteks ini, agar subjek segera keluar dari kepadatan lalu lintas, subjek menyalip kendaraan lain dengan jarak yang sangat dekat.

Untuk komponen unpredictability, respon paling tinggi adalah ketika pengendara lain secara mendadak melewati kendaraan yang dikendarai oleh pengendara yang mendapat respon sebesar $66.75 \%$, sehingga dalam konteks ini, pengendara kendaraan bermotor di Kota Malang merasa jengkel apabila ada pengendara lain secara mendadak melewati atau membalap dengan kecepatan tinggi dan suara knalpot yang berisik. Faktor penyebab perilaku berkendara agresif paling tinggi pada komponen isolation adalah ketika pengendara merasa tersinggung karena gerakan pengendara lain yang mengisyaratkan permusuhan yang dilihat dari kaca jendela atau helm, yang mendapat respon sebesar $50.25 \%$. Dalam konteks ini, pengendara kendaraan bermotor di Kota Malang akan merasa tersinggung jika pengendara melihat pengendara lain menunjukkan jari tengahnya yang dianggap ditunjukkan kepada pengendara tersebut yang terlihat dari balik kaca jendela atau helm. Sementara itu, faktor penyebab perilaku berkendara agresif paling tinggi pada komponen emotional challenges adalah ketika pengendara merasa tertantang untuk melewati jalan yang tidak dapat dilewati kendaraan lain yang mendapat respon sebesar $60.75 \%$, sehingga dalam konteks ini, pengendara kendaraan bermotor di Kota Malang merasa semakin tertantang saat melewati jalan sempit dan berbahaya.

Selanjutnya, dilakukan analisis mengenai bentuk perilaku berkendara agresif para pengguna kendaraan bermotor di Kota 
Malang. Setelah dilakukan analisis data dari 400 responden berdasarkan tiga bentuk perilaku berkendara agresif, maka didapatkan hasil bahwa berdasarkan respon dari 400 subjek penelitian, untuk komponen impatience and inattention, diperoleh data sebanyak 197 subjek menambahkan kecepatan ketika melihat lampu kuning menyala, 167 subjek berkendara secara zig-zag (berpindah-pindah jalur) untuk mencari celah jalan, dan sebanyak 126 subjek memilih mengemudi melebihi batas kecepatan maksimum. Sementara itu, untuk komponen power struggle, diperoleh data bahwa sebanyak 230 subjek memperkecil jarak kedekatan kendaraan mereka dengan kendaraan di depannya untuk menghalangi orang lain yang akan mengambil jalan (menyerobot), dan sebanyak 126 subjek menghalangi orang yang akan berpindah jalur, menolak untuk memberikan jalan. Terakhir, untuk komponen recklessness and road rage, didapatkan bahwa kebanyakan para pengendara kendaraan bermotor di Kota Malang, yaitu sebanyak 189 subjek, memilih mengemudi dengan kecepatan sangat tinggi.

\section{Diskusi}

Berdasarkan survei mengenai bentukbentuk perilaku agresif dalam mengemudi yaitu impatience and inattention (ketidaksabaran dan kecerobohan), power struggle (perlawanan), serta recklessness and road rage (kesembronoan dan amukan jalan), maka ditemukan bahwa perilaku yang paling sering terjadi adalah menambah kecepatan ketika melihat lampu kuning menyala, berkendara secara zig-zag (berpindah-pindah jalur) untuk mencari celah jalan, mengemudi melebihi batas kecepatan maksimum, memperkecil jarak kedekatan kendaraan mereka dengan kendaraan di depannya untuk menghalangi pengendara lain yang akan mengambil jalan (menyerobot), menghalangi pengendara lain yang akan berpindah jalur, menolak untuk memberikan jalan kepada pengendara lain, dan mengemudi dengan kecepatan sangat tinggi.

Hasil survei ini relevan dengan studi yang dilakukan oleh Collado (dalam Dilla, 2008) mengenai perilaku pengemudi yang agresif, di antaranya speeding atau mengebut, tailgating yaitu membuntuti kendaraan lain yang berada di depannya dengan jarak yang sangat dekat, the accordion effect yaitu tidak memberikan kesempatan kepada kendaraan lain untuk memotong masuk dan mengemudikan kendaraan dengan jarak yang sangat dekat dengan kendaraan di depan, fast drivers yaitu bentuk perilaku agresif mengemudi yang banyak mengambil resiko hanya untuk menghindari kemacetan, dan emotional influence yaitu pengaruh emosi dari pengendara itu sendiri.

Sementara itu, berdasarkan penelitian Sofyanida dan Yanuvianti (2016), perilaku berkendara agresif pada kategori impatience and inattention dapat terjadi karena para subjek malas untuk menunggu lampu merah selanjutnya yang selalu lama. Pada akhirnya, subjek memilih untuk mempercepat laju kendaraan agar terbebas dari lampu merah. Padatnya jalan raya menyebabkan subjek mencari jalan yang memungkinkan untuk dilewati meskipun harus berpindah-pindah jalur. Subjek yang ingin cepat sampai tujuan dan dalam kondisi terburu-buru menyebabkan subjek mengemudi melebihi batas kecepatan maksimum. Untuk komponen power struggle, umumnya disebabkan oleh subjek yang merasa kesal jika ada pengemudi lain yang mendahuluinya. Subjek juga akan merasa kalah, lemah, dan tidak mahir dalam berkendara di jalan. Selain itu, subjek menolak untuk memberikan jalan kepada pengemudi 
lain dikarenakan subjek tidak mau jalannya diambil oleh pengemudi lain. Untuk kategori recklessness and road rage, subjek menyukai melaju dengan kencang sehingga terkesan mahir dan tidak dapat disaingi di jalan raya. Akan tetapi pada penelitian ini, hal tersebut lebih berkaitan dengan emosi yang ada dalam diri pengemudi.

Berdasarkan penelitian Muhaz (2013), perilaku berkendara agresif berkaitan dengan tingkat kematangan emosi dari pengendara. Pengendara yang memiliki tingkat kematangan emosi yang tinggi akan mampu berkendara dengan tenang dan berpikir jauh sebelum mengambil tindakan. Sebaliknya, pengendara dengan tingkat kematangan emosi yang rendah akan cenderung meledakan kemarahannya dengan berkendara secara agresif karena kurang memikirkan resiko yang dapat menimpa dirinya maupun pengguna jalan lain. Hal ini juga diperkuat berdasarkan penelitian yang dilakukan oleh Grey (dalam Tasca, 2000) yang mengatakan bahwa perilaku mengemudi berbahaya salah satunya dipengaruhi oleh adanya pelepasan emosional dari pengendara. Ketidakmampuan pengendara untuk mengontrol emosinya, membuat pengendara cenderung melampiaskannya pada saat berkendara. Berdasarkan survei yang peneliti lakukan, hal ini berkatian dengan pengemudi yang mengemudi dengan kecepatan yang sangat tinggi pada recklessness and road rage.

Hasil analisis frekuensi pada 15 faktorfaktor penyebab terjadinya perilaku berkendara agresif mengungkapkan bahwa faktor dominan yang menjadi penyebab terjadinya perilaku berkendara agresif adalah faktor territioriality. Ha ini berarti bahwa seorang penegndara cenderung berkendara agresif disebabkan oleh pengendara lain yang melanggar dan mengancam teritori pengendara tersebut dan sering direspon dengan permusuhan, bahkan dengan sikap tubuh seperti perang dan reaksi agresif berupa pengendara menatap sinis atau tajam jika pengendara lain berbuat onar atau tidak menyenangkan kepada pengendara tersebut. Hal tersebut sesuai dengan penelitian Mizell, Joint, dan Connel (1997) bahwa faktor lingkungan yang dapat menimbulkan perilaku mengemudi berbahaya di antaranya adalah kebisingan, overcrowding, dan territoriality.

Terkait faktor unpredictability, seorang pengendara berkendara secara agresif karena tidak mampu menyesuaikan emosi secara terus-menerus pada hal-hal yang tidak dapat diprediksi, membosankan, kasar, dan kejadian yang berbahaya, seperti pengendara yang merasa marah apabila ada pengendara lain secara mendadak melewati atau membalap dengan kecepatan tinggi dan dengan suara knalpot yang berisik. Hal ini relevan dengan penelitian Dukes, Stephanie, Lessie, Miller, dan Rodgers, (2001) yang menyatakan bahwa kecerobohan pengendara lain seperti pengendara yang menyalip secara tiba-tiba lebih dapat memicu munculnya perilaku berkendara berbahaya dibandingkan dengan keadaan lalu lintas yang menghambat seperti kemacetan dan lampu merah. Kecerobohan pengendara lain direpresentasikan sebagai ancaman yang berbahaya di jalan sehingga hal tersebut membuat pengendara yang merasa terancam melakukan aggressive driving.

Berkaitan dengan faktor restriction, penyebab terjadinya perilaku berkendara agresif adalah ketika melihat pengendara lain dapat melewati kendaraan melalui celah jalan yang dapat dilalui dengan cepat. Restriction bermakna bahwa pengendara merasa terhalangi ketika ingin bergerak ke depan sehingga menimbulkan frustasi dan diikuti 
kecemasan serta intensi untuk keluar dari himpitan tersebut, sehingga pengendara memakai bahu jalan untuk menyalip agar lebih cepat saat terjadi kemacetan. Hasil penelitian Sofyanida dan Yanuvianti (2016) mengungkapkan bahwa seorang pengendara cenderung merasa kendaraan di depannya menghalangi dan tidak memberikan jalan, terutama ketika sedang teburu-buru. Hal tersebut selanjutnya membuat kesal bahkan stres sehingga membuat pengendara menjadi. Stres yang terjadi disebabkan karena apa yang diharapkan tidak sesuai dengan kenyataan. Harapan seorang pengendara adalah tidak ada hambatan apapun ketika di jalan, namun pada kenyataannya masih ada pengemudipengemudi yang dianggap subjek menghalangi, menghambat, dan berjalan lambat dan menurut subjek itu akan membuatnya terlambat sampai tujuan.

Hasil penelitian ini yang berkaitan dengan faktor immobility adalah ketika para pengendara kendaraan bermotor di Kota Malang tidak dapat melewati atau mendahului kendaraan yang berada di depannya. Hal tersebut menyebabkan pengendara membunyikan klakson berkali-kali kepada pengendara yang berjalan lambat di depannya. Seiring dengan hasil penelitian dari Sofyanida dan Yanuvianti (2016), hal tersebut dapat terjadi karena beberapa hal antara lain karena pengendara berada pada situasi terjebak akibat kemacetan, kepadatan, ataupun akibat cuaca seperti hujan dan cuaca yang sangat panas sehingga meningkatkan kecenderungan pengemudi untuk melakukan aggressive driving.

Untuk faktor venting, dapat dijelaskan bahwa pengendara cenderung mendahului kendaraan lain dengan jarak yang sangat dekat, agar pengendara bisa segera keluar dari kepadatan lalu lintas. Hal ini sesuai dengan pendapat Sofyanida dan Yanuvianti (2016) yang menyatakan bahwa ketika menghadapi situasi kemacetan, seseorang akan merasa frustrasi dan menjadi tidak sabar. Pada akhirnya, pengendara cenderung menghalalkan segala cara untuk keluar dari kepadatan dengan melakukan tindakan yang berbahaya.

Sementara itu, berkaitan dengan faktor lack of personal control, pengendara cenderung terpancing emosinya saat suasana lalu lintas macet dan atau kondisi jalan tidak tertib, sehingga ketika pengendara lain memotong jalur pengendara tersebut, maka pengendara tersebut akan terpancing untuk melakukan hal yang sama dengan tujuan membalas. Senada dengan penelitian yang dilakukan oleh Sofyanida dan Yanuvianti (2016), hal tersebut dapat terjadi ketika pengemudi lain menghalangi, hampir menabrak, mendahului, tidak memberikan tanda, serta bergerak lambat ketika lampu sudah mulai hijau. Pengendara akan marahmarah atau membunyikan klakson secara berulang untuk melampiaskan kekesalannya pada pengemudi lain.

Perilaku pengendara yang memotong jalur di jalan raya dan perilakunya diikuti oleh pengendara lain merupakan bentuk faktor being put in danger. Saat pengendara memotong jalur di jalan raya, pengendara akan melihat pengendara lain yang juga mengikuti perilakunya. Menurut Santoso, Maulina, Adystia, dan Oei (2013), tindakan ikut-ikutan seperti itu sangat sering dijumpai di jalan. Jika ada pengendara lain bersikap agresif, maka akan timbul perasaan konformitas atau rasa ingin untuk mengikuti. Hal ini relevan dengan penelitian James (2000) yang menyatakan bahwa perilaku berkendara agresif dipelajari untuk kemudian menjadi kebiasaan yang 
diturunkan dari satu generasi ke generasi berikutknya. Hal serupa juga diungkapkan dalam penelitian Sofyanida dan Yanuvianti (2016), bahwa adanya pengendara lain yang mengikuti perilaku berkendara agresif pengendara lain merupakan bentuk balas dendam atau tidak mau dianggap kalah ketika dipicu oleh pengendara lain yang memulai hal tersebut terlebih dahulu.

Terakhir, berkaitan dengan faktor emotional challenges, pengendara merasa tertantang untuk melewati jalan yang tidak dapat dilewati kendaraan lain. Emotional challenges pada perilaku berkendara agresif umumnya disebabkan oleh para pengendara yang kurang menguasai kecakapan intelegensi emosi yang esensial untuk berkendara di jalan dalam situasi yang menantang, yaitu berupa pengendara merasa semakin tertantang saat melewati jalan sempit dan berbahaya. Hal ini relevan dengan penelitian yang dilakukan oleh Tasca (2000) yang menyatakan bahwa individu yang merasa memiliki keterampilan yang tinggi dalam hal menangani kendaraannya lebih berpeluang untuk melakukan perilaku berkendara agresif. Sebaliknya, individu yang merasa memiliki keterampilan yang tinggi dalam hal keselamatan, kecil kemungkinannya untuk melakukan perilaku berkendara agresif karena individu tersebut lebih mengutamakan keselamatan. Menurut Santoso, dkk. (2013), jika seseorang menganggap sebuah situasi memiliki resiko kecil, maka mereka akan melakukan hal tersebut walaupun tindakan tersebut berbahaya atau melanggar hukum.

\section{Daftar Pustaka}

Dilla, B. (2008). Perbedaan perilaku agresif mengemudi pada pengendara sepeda motor dengan kepribadian tipe A dan B. Skripsi. UIN Syarif Hidayatullah.

Dukes, R. L., Stephanie L. C., Lessie, T. J., Miller, T. L., \& Rodgers, S. E. (2001). Effects of aggressive driving and driver characteristics on road rage. The Social Science Journal, 38(2), 323-331.

James, L., \& Nahl, D. (2000). Road Rage and Aggressive Driving Steering Clear of Highway Warfare. Amhest, NY: Promothens Books.

Santoso, G. A., Maulina, D., Adystia, C., \& Oei, T. P. (2013). The influence of number of passengers and music genre on driving speed of young adult angkot drivers. Journal Transportation Research Part F: Traffic Psychology and Behavior, 18, 1-10.

Mizell, L. B., Joint, M., \& Connel, D. (1997). Aggressive Driving: Three Studies. Research Report for the American Automobile Association: Foundation for Traffic Safety. Washington, D.C.: AAA Foundation for Traffic Safety.

Muhaz, M. (2013). Kematangan emosi dengan aggressive driving pada mahasiswa. Jurnal Online Psikologi, 1(2).

Neuman, W. L. (2013). Metode Penelitian Sosial: Pendekatan Kualitatif dan Kuantitatif Edisi Ketujuh. Jakarta: Indeks.

Sofyanida, T., \& Yanuvianti, M. (2016). Studi deskriptif mengenai perilaku mengemudi agresif pada mahasiswa pengendara sepeda motor di Kota Bandung. Prosiding Psikologi Seminar Penelitian Sivitas Akademia Unisba, 2, 943-949.

Tasca, L. (2000, October). A review of the 
PERILAKU BERKENDARA AGRESIF

literature on aggressive driving research. Paper presented at the Aggressive Driving Issues Conference, Ontario, Canada. 